\title{
RÓŻNICE W SPOSOBIE PREZENTOWANIA INFORMACJI DOTYCZĄCYCH WSKAŹNIKÓW EFEKTYWNOŚCI ŚRODOWISKOWEJ
}

Jednym z wymogów Systemu Ekozarządzania i Audytu (EMAS) jest publikowanie deklaracji środowiskowej. Deklaracja jest formą sprawozdawczości środowiskowej, w której organizacje zamieszczają między innymi informacje dotyczące: systemu zarządzania środowiskowego, aspektów środowiskowych, celów i zadań środowiskowych, a także efektów prowadzonej działalności środowiskowej (w tym wskaźników efektywności środowiskowej). Rozporządzenie EMAS określa jaka powinna być minimalna zawartość deklaracji środowiskowej, ale to organizacje decydują na ile szczegółowe informacje zostaną zawarte w deklaracji oraz jaka będzie jej struktura i układ.

Rozporządzenie EMAS (Załącznik IV) wymienia sześć głównych wskaźników efektywności środowiskowej, które powinny zostać ujęte w deklaracji środowiskowej. Dotyczą one: efektywności energetycznej, efektywnego wykorzystania materiałów, wody, odpadów, różnorodności biologicznej oraz emisji. Organizacje mogą także ujmować w deklaracji dodatkowe wskaźniki, jeżeli uznają je za znaczące dla zidentyfikowanych, znaczących aspektów środowiskowych.

Deklaracje środowiskowe dostarczają wielu danych jakościowych oraz ilościowych, dotyczących działalności środowiskowej danej organizacji. Ich analiza jednak

i porównywanie danych, zawartych $\mathrm{w}$ poszczególnych deklaracjach nie jest zadaniem łatwym. Powodem są różnice w sposobie prezentowania informacji przez poszczególne organizacje.

W artykule opisano różnice $\mathrm{w}$ sposobie prezentowania informacji (dotyczących wskaźników efektywności środowiskowej) w deklaracjach środowiskowych organizacji, zarejestrowanych w systemie EMAS w Polsce. Dokonano analizy źródeł wtórnych, w postaci deklaracji środowiskowych, dostępnych na stronie internetowej systemu EMAS. Badaniem objęto całą populację - wszystkie organizacje, zarejestrowane w systemie EMAS w Polsce na dzień 2402 2014r.

Słowa kluczowe: EMAS, wskaźniki efektywności środowiskowej, deklaracja środowiskowa.

\section{WPROWADZENIE}

Jednym z wymogów Systemu Ekozarządzania i Audytu (EMAS) jest publikowanie deklaracji środowiskowej. Powinna być ona udostępniana wszystkim osobom, zainteresowanym działalnością środowiskową organizacji. Deklaracja stanowi formę sprawozdawczości środowiskowej, w której organizacje mają obowiązek zamieszczać informacje, dotyczące m.in.: ich systemu zarządzania środowiskowego, aspektów środowiskowych, celów i zadań środowiskowych, a także efektów prowadzonej

\footnotetext{
${ }^{1}$ Mgr Jadwiga Nycz - Wróbel, Wydział Zarządzania, Politechnika Rzeszowska, ul. Poznańska 1, 35-084 Rzeszów, tel. 1786512 04, e-mail: jnw@prz.edu.pl
} 
działalności środowiskowej (w tym wskaźników efektywności środowiskowej).

Deklaracje środowiskowe dostarczają wielu danych jakościowych oraz ilościowych, dotyczących działalności środowiskowej danej organizacji. Ich analiza jednak i porównywanie danych, zawartych w poszczególnych deklaracjach nie jest zadaniem łatwym. Powodem są różnice w sposobie prezentowania informacji przez poszczególne organizacje. Rozporządzenie EMAS jednoznacznie określa, jaka powinna być minimalna zawartość deklaracji środowiskowej. Jednak forma prezentacji poszczególnych informacji różni się w poszczególnych organizacjach.

Celem artykułu było opisanie różnic w sposobie prezentowania informacji, dotyczących wskaźników efektywności środowiskowej, przez organizacje zarejestrowane w systemie EMAS. Analizie poddano deklaracje wszystkich organizacji, aktualnie zarejestrowanych w systemie EMAS w Polsce, co pozwoliło na uogólnienie wniosków.

\section{WYMOGI ROZPORZĄDZENIA EMAS DOTYCZĄCE DEKLARACJI ŚRODOWISKOWEJ}

Deklaracja środowiskowa, jak definiuje Rozporządzenie EMAS to: „wyczerpująca informacja, udzielana społeczeństwu i innym zainteresowanym stronom, dotycząca takich elementów funkcjonowania organizacji, jak:

- struktura i działalność organizacji,

- polityka środowiskowa i system zarządzania środowiskowego,

- aspekty środowiskowe i wpływ na środowisko,

- program, cele i zadania środowiskowe,

- efekty działalności środowiskowej i zgodność z mającymi zastosowanie obowiązkami prawnymi dotyczącymi środowiska."2

Deklaracja środowiskowa stanowi jeden z elementów odróżniających system EMAS od innych systemów zarządzania środowiskowego. Zgodnie z wymogami Rozporządzenia EMAS, deklaracja musi być publikowana i udostępniana wszystkim osobom, zainteresowanym działalnością środowiskową organizacji. Rozporządzenie definiuje jaka powinna być minimalna zawartość deklaracji środowiskowej, ale to organizacje decydują na ile szczegółowe informacje zostaną w niej zawarte oraz jaka będzie struktura oraz układ deklaracji. Bardziej szczegółowe wymogi, dotyczące deklaracji środowiskowej, zawarte zostały w Załączniku IV do Rozporządzenia EMAS III. Zgodnie z tym załącznikiem, w treści deklaracji środowiskowej, powinny znaleźć się przynajmniej następujące informacje $\mathrm{e}^{3}$ :

a) jasny, jednoznaczny opis organizacji, która stara się o rejestrację (lub jest już zarejestrowana) w systemie EMAS. Organizacja powinna zawrzeć opis swojej działalności, produktów lub usług oraz opis wszelkich powiązań z organizacjami macierzystymi (w stosowanych przypadkach),

b) polityka środowiskowa oraz opis systemu zarządzania środowiskowego,

c) opis wszystkich znaczących, bezpośrednich i pośrednich aspektów środowiskowych, powodujących znaczący wpływ organizacji na środowisko,

d) opis celów i zadań środowiskowych, w odniesieniu do znaczących aspektów

\footnotetext{
${ }_{3}^{2}$ Rozporzadzenie Parlamentu Europejskiego i Rady (WE) nr 1221/2009, s.5.
}

${ }^{3}$ Tamże, s. 36. 
środowiskowych oraz wpływu na środowisko,

e) informacje dotyczące efektów działalności środowiskowej organizacji,

w porównaniu do jej celów i zadań środowiskowych oraz w odniesieniu do znaczącego wpływu na środowisko. Informacje te opierają się przede wszystkim na prezentacji głównych i/lub dodatkowych wskaźnikach efektywności środowiskowej,

f) inne elementy dotyczące efektów działalności środowiskowej, w tym dane dotyczące efektywności w porównaniu z limitami, wynikającymi z przepisów prawnych,

g) odniesienie do mających zastosowanie $\mathrm{w}$ organizacji przepisów prawnych, dotyczących środowiska,

h) nazwisko i numer akredytacji lub licencji weryfikatora środowiskowego (który dokonał walidacji deklaracji środowiskowej) oraz data walidacji.

Załącznik IV do Rozporządzenia EMAS zawiera także wymagania, odnośnie wskaźników efektywności środowiskowej, ujmowanych w sprawozdawczości. Rozporządzenie wymienia sześć głównych wskaźników efektywności środowiskowej, które powinny zostać ujęte w deklaracji środowiskowej, przez organizacje zarejestrowane w systemie EMAS. Należą do nich wskaźniki, dotyczące: efektywności energetycznej, efektywnego wykorzystania materiałów, wody, odpadów, różnorodności biologicznej oraz emisji. Główne wskaźniki efektywności środowiskowej, dotyczą tzw. kluczowych obszarów działalności środowiskowej organizacji. Rozporządzenie dopuszcza możliwość zrezygnowania $\mathrm{z}$ podawania $\mathrm{w}$ sprawozdawczości głównych wskaźników efektywności środowiskowej, w sytuacji, gdy nie mają one znaczenia dla zidentyfikowanych przez organizację, znaczących aspektów środowiskowych lub, gdy wskaźniki te, nie są związane $\mathrm{w}$ żaden sposób $\mathrm{z}$ rodzajem prowadzonej przez organizację działalności. Organizacje mogą także ujmować w deklaracji dodatkowe wskaźniki, jeżeli uznają je za znaczące dla zidentyfikowanych, znaczących aspektów środowiskowych.

Deklaracja środowiskowa może występować w formie drukowanej lub elektronicznej (możliwość prezentacji deklaracji, w formie elektronicznej wprowadziło dopiero Rozporządzenie EMAS III, poprzednie dwie wersje wymagały deklaracji $\mathrm{w}$ formie papierowej). Zgodnie z wymogami Załącznika IV do Rozporządzenia EMAS, organizacja musi być w stanie wykazać, że każda osoba, zainteresowana efektami jej działalności środowiskowej, może w łatwy sposób uzyskać dostęp do jej deklaracji środowiskowej.

Organizacje, zarejestrowane w systemie EMAS mają obowiązek opracowywać deklarację środowiskową, co trzy lata (zgodnie z artykułem 6 Rozporządzenia EMAS). W przypadku małych organizacji, okres ten może zostać wydłużony do czterech lat. W okresach pośrednich, zarejestrowane organizacje mają obowiązek przygotowywać zaktualizowaną deklarację środowiskową, która powinna zawierać przynajmniej informacje, dotyczące ${ }^{4}$ :

- efektów działalności środowiskowej, w porównaniu z celami i zadaniami środowiskowymi, w odniesieniu do znaczącego wpływu organizacji na środowisko,

- innych elementów, dotyczących efektów działalności środowiskowej $\mathrm{w}$ porównaniu do limitów, zawartych $\mathrm{w}$ przepisach prawa, dotyczących

${ }^{4}$ Rozporządzenie Parlamentu Europejskiego i Rady (WE) nr 1221/2009, s.36. 
środowiska,

- odniesienia do mających zastosowanie w organizacji przepisów prawnych, dotyczących środowiska,

- danych weryfikatora środowiskowego, który przeprowadził weryfikację oraz daty walidacji.

Zarówno deklaracja środowiskowa przygotowana po raz pierwszy, jak i jej zaktualizowana wersja, muszą zostać zwalidowane przez weryfikatora środowiskowego. „Walidacja oznacza potwierdzenie przez weryfikatora środowiskowego, który przeprowadził weryfikację, że informacje i dane zawarte w deklaracji środowiskowej i zaktualizowanej deklaracji środowiskowej organizacji są rzetelne, wiarygodne i prawidłowe oraz spełniają wymogi Rozporządzenia EMAS.",

Pomimo wymogów Rozporządzenia EMAS, w odniesieniu do minimalnej zawartości deklaracji środowiskowej, sposób podawania informacji przez poszczególne organizacje może się różnić. Różnice te dotyczą między innymi informacji, dotyczących wskaźników efektywności środowiskowej.

\section{CHARAKTERYSTYKA ORGANIZACJI OBJĘTYCH BADANIEM}

W Polsce, na dzień 2402 2014r., w systemie EMAS zarejestrowanych było 44 organizacje. Wykaz organizacji zarejestrowanych w tym czasie w systemie EMAS zawarto w Tabeli 1. Należy w tym miejscu podkreślić, że rejestr organizacji, które wdrożyły system EMAS jest na bieżąco aktualizowany i liczba zarejestrowanych organizacji, może ulegać zmianom, nawet w krótkim okresie czasu (ze względu na przystąpienie nowej organizacji do rejestru EMAS lub zawieszenie organizacji w rejestrze).

Tabela 1. Wykaz organizacji, zarejestrowanych w systemie EMAS w Polsce, na dzień 24 lutego 2014 r.

\begin{tabular}{|l|l|}
\hline Lp. & \multicolumn{1}{|c|}{ ORGANIZACJA } \\
\hline 1. & Centrum Onkologii im. prof. F. Łukaszczyka - BYDGOSZCZ \\
\hline 2. & Przedsiębiorstwo Budowy Dróg i Mostów Sp. z o.o. - MIŃSK MAZOWIECKI \\
\hline 3. & RAFAKO S.A. - RACIBÓRZ \\
\hline 4. & Wojewódzki Fundusz Ochrony Środowiska i Gospodarki Wodnej w Katowicach - KATOWICE \\
\hline 5. & Bombardier Transportation Polska Spółka z o.o. - Wrocław \\
\hline 6. & Dolina Nidy Sp. z o.o. - PINCZÓW \\
\hline 7. & $\begin{array}{l}\text { Urząd Miasta w Trzebini (Wydizał Gospodarki Ochrony środowiska Rolnictwa i Leśnictwa) - } \\
\text { TRZEBINIA }\end{array}$ \\
\hline 8. & $\begin{array}{l}\text { TAURON Wytwarzanie S.A. - Oddział Elektrownia Łaziska w Łaziskach Górnych - ŁAZISKA } \\
\text { GÓRNE }\end{array}$ \\
\hline 9. & EDF Wybrzeże S.A - GDAŃSK \\
\hline 10. & Przedsiębiorstwo Wodociągów i Kanalizacji Okręgu Częstochowskiego S.A. - CZĘSTOCHOWA \\
\hline 11. & Arctic Paper Kostrzyn S.A. - KOSTRZYN NAD ODRA \\
\hline 12. & $\begin{array}{l}\text { Międzygminne Przedsiębiorstwo Gospodarki Odpadami i Energetyki Odnawialnej "MASTER" } \\
\text { Sp. z o.o. - } \\
\text { TYCHY }\end{array}$ \\
\hline
\end{tabular}

\footnotetext{
${ }^{5}$ Tamże, s.5.
} 


\begin{tabular}{|c|c|}
\hline 13. & Alpha TECHNOLOGY Sp. z o.o. spółka komandytowo-akcyjna - DOBCZYCE \\
\hline 14. & $\begin{array}{l}\text { PGE Górnictwo i Energentyka Konwencjonalna S.A. - Oddział Zespół Elektrowni Dolna Odra - } \\
\text { NOWE CZARNOWO }\end{array}$ \\
\hline 15. & Częstochowskie Przedsiębiorstwo Komunalne Sp.z o.o. - CZĘSTOCHOWA \\
\hline 16. & Przedsiębiorstwo Gospodarki Wodnej i Rekultywacji S.A. - JASTRZĘBIE ZDRÓJ \\
\hline 17. & Regionalne Centrum Gospodarki Wodno- Ściekowej - TYCHY \\
\hline 18. & TAURON Wytwarzanie S.A. - Oddział Elektrownia Jaworzno III w Jaworznie - JAWORZNO \\
\hline 19. & KOBA Organizacja Odzysku S.A. - KRAKÓW \\
\hline 20. & TAURON Wytwarzanie Spółka Akcyjna-Oddział Elektrownia Siersza w Trzebini - TRZEBINIA \\
\hline 21. & Cementownia Warta S.A. - DZIAŁOSZYN \\
\hline 22. & Petrochemia-Blachownia S.A. - KĘDZIERZYN-KOŹLE \\
\hline 23. & Przedsiębiorstwo Produkcji Kruszywa i Usług Geologicznych "KRUSZGEO" S.A. - RZESZÓW \\
\hline 24. & CEMEX sp. z o.o. - CHEŁM \\
\hline 25. & Ministerstwo Środowiska - WARSZAWA \\
\hline 26. & MAN Trucks Sp. z.o.o. - NIEPOŁOMICE \\
\hline 27. & AB S.A. - WROCŁAW \\
\hline 28. & Miejskie Przedsiębiorstwo Wodociągów i Kanalizacji w Lublinie Sp. z o.o. - LUBLIN \\
\hline 29. & JAGO-PRO Sp. z o.o. - JAWORZNO \\
\hline 30. & Urząd Miejski Wrocławia - WROCŁAW \\
\hline 31. & $\begin{array}{l}\text { TAURON Wytwarzanie S.A. - Oddział Zespół Elektrociepłowni Bielsko-Biała - BIELSKO- } \\
\text { BIAŁA }\end{array}$ \\
\hline 32. & ALBA MPGK Sp. z o.o. - DĄBROWA GÓRNICZA \\
\hline 33. & DOL-EKO Organizacja Odzysku S.A. - WROCŁAW \\
\hline 34. & TOM Organizacja Odzysku S.A. - SZCZECIN \\
\hline 35. & Organizacja Odzysku Odpadów i Opakowań „EKOLA" S.A. - GDAŃSK \\
\hline 36. & PONAR WADOWICE S.A. - WADOWICE \\
\hline 37. & $\begin{array}{l}\text { Ośrodek Główny Instytutu Meteorologii i Gospodarki Wodnej - Państwowego Instytutu } \\
\text { Badawczego }\end{array}$ \\
\hline 38. & ALBA Południe Polska Sp. z o.o. - DĄBROWA GÓRNICZA \\
\hline 39. & Zachodniopomorskie Centrum Onkologii - SZCZECIN \\
\hline 40. & Zakład Utylizacji Odpadów Sp. z o.o. - GORZÓW WIELKOPOLSKI \\
\hline 41. & Przedsiębiorstwo „LABTAR" Sp. z o.o. - TARNÓW OPOLSKI \\
\hline 42. & TAURON Wytwarzanie Spółka Akcyjna - Oddział Elektrownia Łagisza - BĘDZIN \\
\hline 43. & H\&M HENNES \& MAURITZ LOGISTICS Sp. z o.o. - GĄDKI \\
\hline 44. & Konsorcjum Olejów Przepracowanych Organizacja Odzysku S.A. - JEDLICZE \\
\hline
\end{tabular}

Źródło: Opracowanie własne na podstawie www.gdos.gov.pl.

Działalność, prowadzona przez organizacje zarejestrowane w systemie EMAS, klasyfikowana jest zgodnie ze statystyczną klasyfikacją działalności gospodarczej Wspólnoty Europejskiej - NACE (Rozporządzenie (WE) nr 1893/2006 Parlamentu Europejskiego i Rady z dnia 20 grudnia 2006 r.). Zgodnie z tą klasyfikacją, polskie organizacje zarejestrowane w systemie EMAS prowadzą następujący rodzaj działalności:

- $27,27 \%$ prowadzi działalność produkcyjną,

- $13,64 \%$ prowadzi działalność związaną z wytwarzaniem energii elektrycznej (NACE 35.11),

- $11,36 \%$ prowadzi działalność związaną ze zbieraniem odpadów innych niż niebezpieczne (NACE 38.11) - 60\%, wśród tych organizacji zajmuje się także zbieraniem odpadów niebezpiecznych (NACE 38.12),

- 9,09\% prowadzi działalność związaną z rekultywacją i pozostałymi usługami, związanymi z gospodarką odpadami ( NACE 38.32), 
- 9,09\% prowadzi działalność związaną z poborem, uzdatnianiem i dostarczaniem wody i/lub odprowadzaniem i oczyszczaniem ścieków

- $6,82 \%$ prowadzi działalność związaną z kierowaniem podstawowymi rodzajami działalności publicznej (NACE 84.11),

- 4,55\% prowadzi działalność szpitali (NACE 86.10),

- wśród pozostałych $18,18 \%$ organizacji, każda prowadzi inny rodzaj działalności.

\section{WYNIKI ANALIZY DEKLARACJI ŚRODOWISKOWYCH}

Na wstępie należy zaznaczyć, że analiza deklaracji nie była zadaniem łatwym, ze względu na różnice w sposobie prezentacji informacji, przez poszczególne organizacje. $\mathrm{O}$ trudnościach, związanych $\mathrm{z}$ analizą i porównywaniem treści deklaracji środowiskowych pisali także Erkko, Melanin oraz Mickwitz, w artykule, dotyczącym fińskich organizacji, zarejestrowanych $\mathrm{w}$ systemie EMAS. ${ }^{6}$ Uwagi, dotyczące trudności w analizie sprawozdawczości środowiskowej zawarto także w badaniu EVER: Evaluation of EMAS and Eco-Label for their Revision, Report 2: Research Findings. ${ }^{7}$

W wyniku przeprowadzonej analizy, autorka znalazła klika różnic, dotyczących sposobu prezentowania informacji, dotyczących wskaźników efektywności środowiskowej.

Pierwsza różnica, dotyczyła typu informacji, zawartych w deklaracjach. Zdecydowana większość organizacji, objętych badaniem $(70,45 \%)$, zawarła w sprawozdawczości oprócz danych ilościowych (wartości liczbowe poszczególnych wskaźników), także dane jakościowe. Dane jakościowe, stanowiły formę opisu, dotyczącego m.in.: podjętych przez organizację działań, w celu zmniejszenia wartości głównych wskaźników

w poszczególnych latach; uzasadnienia, z czego wynikał ewentualny wzrost wartości wskaźnika w danym roku; działań, jakie zamierza podjąć organizacja, aby jeszcze zmniejszyć wartość poszczególnych wskaźników w kolejnych latach. Pozostałe 29,55\% organizacji, zawarło w sprawozdawczości wyłącznie dane ilościowe. Organizacje te podały w deklaracjach wyłącznie wartości liczbowe poszczególnych wskaźników, bez dodatkowego opisu.

Kolejna różnica, w zakresie sposobu prezentowania informacji, dotyczących wskaźników efektywności środowiskowej, dotyczyła zestawienia wartości uzyskanych wskaźników, na tle limitów i pozwoleń, wynikających z przepisów prawa, dotyczących środowiska.

Z analizy wynika, że 41,03\% organizacji, podało w sprawozdawczości wartości uzyskanych wskaźników, na tle tych limitów. Należy w tym miejscu podkreślić, że analizy, dotyczącej tego aspektu, dokonano wśród 88,64\% organizacji, których dotyczą limity i pozwolenia, wynikające z przepisów prawa - pozostałe $11,36 \%$ organizacji, z racji typu prowadzonej działalności nie podlega limitom i pozwoleniom, wynikającym z przepisów prawnych, dotyczących środowiska. Pozostałe 58,97\% organizacji nie zawarło w sprawozdawczości zestawienia wartości uzyskanych wskaźników, na tle

\footnotetext{
${ }^{6}$ Erkko S., Melanen M., Mickwitz P., Eco-efficiency in the Finnish EMAS reports - a buzz world? „Journal of Cleaner Production 13”,2005, pp.802-803.

${ }^{7}$ EVER: Evaluation of EMAS and Eco-Label for their Revision. Report 2: Research Findings, 26 December 2005, s. 7.
} 
limitów i pozwoleń, wynikających z przepisów prawa, dotyczących środowiska.

Kolejna różnica dotyczyła wyszczególnienia w sprawozdawczości (lub nie) wartości uzyskanych wskaźników, dla poszczególnych typów wytworzonych odpadów. Analiza, dotycząca tego aspektu, przeprowadzona została ponownie wśród 88,64\% wszystkich organizacji (których działalność ma wpływ na wytworzenie odpadów). Pozostałe 11,36\% polskich organizacji, zarejestrowanych w systemie EMAS nie prowadzi działalności, która ma wpływ na wytworzenie odpadów.

$\mathrm{Z}$ analizy wynika, że 69,23\% organizacji (których działalność może mieć wpływ na wytworzenie odpadów), ujęło w deklaracji środowiskowej wartości uzyskanych wskaźników efektywności, dla poszczególnych typów wytworzonych odpadów. Pozostałe $30,77 \%$ organizacji to takie, które nie ujęły w deklaracji wartości wskaźników dla poszczególnych typów wytworzonych odpadów. Do tej grupy autorka zaliczyła także organizacje, które wymieniły typy wytworzonych odpadów, ale nie wyszczególniły dla nich wartości uzyskanych wskaźników efektywności środowiskowej.

Kolejna różnica dotyczy przedziału czasowego, w którym badane organizacje podały wartości wskaźników efektywności środowiskowej.

Tabela 2. Przedział czasowy, w jakim polskie organizacje, zarejestrowane w systemie EMAS, podały w sprawozdawczości wartości wskaźników efektywności środowiskowej.

\begin{tabular}{|c|c|}
\hline Przedzial czasowy & Procent organizacji \\
\hline 1 rok & 2.27 \\
\hline 2 koleine lata & 22.73 \\
\hline 3 kolejne lata & 27,27 \\
\hline 4 koleine lata & 9.1 \\
\hline 5koleinych lat & 11,36 \\
\hline 6 koleinych lat & 6,82 \\
\hline 7 koleinych lat & 2.27 \\
\hline 10 koleinych lat & 2.27 \\
\hline $\begin{array}{c}\text { Różny przedział czasowy dla poszczególnych form } \\
\text { prezentacji wskaźników }\end{array}$ & 15,91 \\
\hline
\end{tabular}

Źródło: Opracowanie własne na podstawie deklaracji środowiskowych, dostępnych na stronie www.gdos.gov.pl.

Z analizy wynika, że organizacje zarejestrowane w systemie EMAS, podają w sprawozdawczości wartości uzyskanych wskaźników efektywności środowiskowej, w różnych przedziałach czasowych. Wśród organizacji były takie, które podały wartości wskaźników dla jednego roku $(2,27 \%)$, były także takie, które podały wartości wskaźników dla 10 kolejnych lat $(2,27 \%)$. Najwięcej organizacji podało wartości wskaźników dla dwóch lub trzech kolejnych lat. Stanowiły one $22,73 \%$ oraz $27,27 \%$, wśród wszystkich organizacji, objętych badaniem. Były także takie organizacje, które podały wartości uzyskanych wskaźników w różnych przedziałach czasowych (różne przedziały czasowe dla różnych form prezentowania informacji). Organizacje te opracowały tabelę zbiorczą dla wszystkich, głównych wskaźników dla okresu dwóch do czterech kolejnych lat (w zależności od organizacji), natomiast wykresy i /lub dane 
jakościowe opracowały dla dłuższych przedziałów czasowych.

O trudnościach, związanych $\mathrm{z}$ analizą wskaźników, ze względu na różny przedział czasowy, w jakim są one podawane w sprawozdawczości, pisali także: Erkko, Melanin oraz Mickwitz. ${ }^{8}$

Zdaniem autorki artykułu, bardzo dużą trudność podczas analizy wskaźników efektywności środowiskowej, przysparza brak jednolitych jednostek miar, w jakich organizacje podają wartości wskaźników.

Tabela 3. Jednostki miar, stosowane przez polskie organizacje, zarejestrowane w systemie EMAS do wyrażenia w sprawozdawczości wartości wskaźników efektywności środowiskowej.

\begin{tabular}{|c|c|c|}
\hline $\begin{array}{l}\text { Glówny wskaźnik } \\
\text { efektywności } \\
\text { środowiskowej }\end{array}$ & $\begin{array}{c}\text { Jednostka miary } \\
\text { zastosowana do wyrażenia } \\
\text { wartości wskaźnika }\end{array}$ & Procent organizacji \\
\hline \multirow{3}{*}{$\begin{array}{l}\text { Efektywność energetyczna - } \\
\text { zużycie energii elektrycznej }\end{array}$} & MWh & 76,92 \\
\hline & $\mathrm{kWh}$ & 10,26 \\
\hline & GJ & 12,82 \\
\hline \multirow{3}{*}{ Woda - zużycie } & $\mathrm{m} 3$ & 94,6 \\
\hline & tys.m3 & 2,7 \\
\hline & $\mathrm{mg}$ & 2,7 \\
\hline \multirow{4}{*}{$\begin{array}{l}\text { Odpady (w tym odpady } \\
\text { komunalne) }\end{array}$} & $\mathrm{mg}$ & 74,37 \\
\hline & $\mathrm{kg}$ & 20,51 \\
\hline & tony & 2,56 \\
\hline & $\mathrm{m} 3$ & 2,56 \\
\hline \multirow{2}{*}{ Różnorodność biologiczna } & $\mathrm{m} 2$ & 98 \\
\hline & ha & 2,0 \\
\hline \multirow{3}{*}{ Emisje gazów cieplarnianych } & $\mathrm{mg}$ & 63,33 \\
\hline & $\mathrm{kg}$ & 30 \\
\hline & tony & 6,66 \\
\hline \multirow{3}{*}{ Emisje do atmosfery } & $\mathrm{mg}$ & 32,26 \\
\hline & $\mathrm{kg}$ & 64,52 \\
\hline & tony & 3,22 \\
\hline
\end{tabular}

Źródło: Opracowanie własne na podstawie deklaracji środowiskowych, dostępnych na stronie www.gdos.gov.pl.

W Tabeli 5 przedstawiono różnice, dotyczące jednostek miar, w jakich organizacje,

${ }^{8}$ Erkko S., Melanen M., Mickwitz P., Eco-efficiency in the Finnish EMAS reports - a buzz world? „Journal of Cleaner Production 13”,2005, pp.802. 
objęte badaniem, podały wartości wskaźników.

$\mathrm{W}$ analizie, dotyczącej jednostek miar, w jakich organizacje prezentowały w sprawozdawczości główne wskaźniki efektywności środowiskowej, autorka artykułu nie uwzględniła wskaźnika, dotyczącego efektywnego gospodarowania zasobami. Uzasadnia to tym, że organizacje objęte badaniem prowadzą różne rodzaje działalności.

W zależności od rodzaju prowadzonej działalności, organizacje wykorzystują różne zasoby, w związku z czym, jednostki w jakich są podawane ich wartości, także w sposób oczywisty będą się różnić.

Wskaźnik dotyczący efektywności energetycznej (poddano analizie wskaźnik, dotyczący zużycia energii elektrycznej), wykazało w swojej sprawozdawczości 88,64\% organizacji, objętych badaniem (dla pozostałych organizacji wskaźnik ten nie jest znaczący dla ich aspektów środowiskowych). Zdecydowana większość w grupie tych organizacji, wyraziła wartość tego wskaźnika w MWh (81,08\%); kolejne 12,82\% organizacji w GJ; natomiast pozostałe 10,27\% organizacji w kWh.

Wskaźnik, dotyczący zużycia wody (został ujęty w sprawozdawczości przez 84,09\% wszystkich organizacji, objętych badaniem), 94,59\% organizacji podało w m3; kolejne $2,7 \%$ organizacji w tys.m3, natomiast pozostałe $2,7 \%$ organizacji w mg.

Wskaźnik dotyczący różnorodności biologicznej, podano w zdecydowanej większości w m2 $(92 \%)$ oraz w ha $(8 \%)$. Wskaźnik ten ujęło w sprawozdawczości $56,82 \%$ wśród wszystkich organizacji, objętych badaniem.

Wskaźnik dotyczący ilości wytworzonych odpadów (wśród 88,64\% organizacji, które ujęły go w deklaracji środowiskowej), podano w mg (74,37\%); kg (20,51\%); tonach $(2,56 \%)$ oraz w m3 $(2,56 \%)$.

Wskaźnik, dotyczący emisji gazów cieplarnianych (wśród 68,18\% organizacji, które ujęły go w sprawozdawczości), podano w mg $(63,34 \%), \mathrm{kg}(30 \%)$ oraz w tonach $(6,66 \%)$.

Wskaźnik, dotyczący emisji (związków innych niż gazy cieplarniane) do atmosfery (wśród 70,45\% organizacji, które ujęły ten wskaźnik w sprawozdawczości), podano w mg $(32,26 \%), \mathrm{kg}(64,52 \%)$ oraz w tonach $(3,22 \%)$.

O trudnościach związanych z porównywaniem informacji, dotyczących wskaźników efektywności środowiskowej (zawartych w deklaracjach środowiskowych), czytamy także w badaniu EVER: Evaluation of EMAS and Eco-Label for their Revision, Report 2: Research Findings. ${ }^{9}$ Autorzy badania także podkreślają fakt braku harmonizacji w jednostkach miar, stosowanych do wyrażenia wartości wskaźników.

Ostatnia różnica dotyczyła wartości, w jakich badane organizacje wyraziły całkowity roczny wynik (zgodnie z Rozporządzeniem EMAS jest on określany jako liczba B i stanowi jeden z trzech elementów wskaźników efektywności środowiskowej).

Tabela 4. Jednostki miar, w jakich polskie organizacje, zarejestrowane w systemie EMAS, podały w sprawozdawczości całkowity, roczny wynik organizacji (liczba B).

\begin{tabular}{|c|c|}
\hline Jednostka miary & Procent organizacji \\
\hline Przeliczenie na 1 pracownika & 27,28 \\
\hline Przeliczenie na mg lub tonę produktu/surowca & 15,91 \\
\hline Roczny wynik & 11,36 \\
\hline Wielkość produkcji (w przypadku niektórych & 22,73 \\
\hline
\end{tabular}

${ }^{9}$ EVER: Evaluation of EMAS and Eco-Label for their Revision. Report 2: Research Findings, 26 December 2005, s. 7. 


\begin{tabular}{|c|c|}
\hline $\begin{array}{c}\text { organizacji to produkcja energii elektrycznej } \\
\text { brutto) }\end{array}$ & \\
\hline $\begin{array}{c}\text { Całkowita ilość odpadów } \\
\text { przyjętych/dostarczonych do zakładu w ciągu } \\
\text { roku }\end{array}$ & 6,82 \\
\hline Wielkość przychodów w danym roku & 11,36 \\
\hline Całkowita generowana wartość dodana brutto & 2,27 \\
\hline $\begin{array}{c}\text { Wprowadzona do kotła energia chemiczna } \mathrm{w} \\
\text { paliwie }\end{array}$ & 2,27 \\
\hline
\end{tabular}

Źródło: Opracowanie własne na podstawie deklaracji środowiskowych, dostępnych na stronie www.gdos.gov.pl.

$\mathrm{Z}$ analizy wynika, że organizacje objęte badaniem, podają w sprawozdawczości wartość całkowitego wyniku, uzyskanego w danym roku, w różnych jednostkach miar. Jest to uzasadnione faktem różnego rodzaju prowadzonej przez te organizacje działalności. Rozporządzenie EMAS podaje przykłady jednostek miar, które można wykorzystać do wyrażenia liczby B, określającej roczny, uzyskany wynik, ale dopuszcza także możliwość zastosowania przez organizacje innych jednostek miar. Najwięcej organizacji, objętych badaniem wyraziło swój roczny, uzyskany wynik w przeliczeniu na 1 pracownika $(27,28 \%)$ oraz w przeliczeniu na wielkość produkcji $(22,73 \%)$. Kolejne $15,91 \%$ wyraziło roczny wynik w przeliczeniu na mg lub tonę produktu/surowca. Badane organizacje, podały także liczbę $\mathrm{B}$, jako roczny wynik (11,36\%), który w zależności od rodzaju prowadzonej działalności oznaczał: ilość wysłanego wyrobu finalnego z zakładu, wyrażoną w tonach; całkowitą ilość przepompowanej wody; roczną ilość pobranej wody i przyjętych ścieków. Kolejne 11,36\% organizacji, objętych badaniem wyraziło całkowity, roczny wynik jako wielkość przychodów w danym roku. Organizacje wyraziły także roczny wynik, jako całkowitą ilość odpadów przyjętych/dostarczonych do zakładu $(6,82 \%)$; całkowitą generowaną wartość dodaną brutto $(2,27 \%)$ oraz wartość wprowadzonej do kotła energii chemicznej w paliwie $(2,27 \%)$.

Różnice dotyczyły także liczby stron, na których podano informacje, dotyczące wskaźników efektywności środowiskowej. Rozbieżności w tym zakresie były bardzo duże. Niektóre organizacje prezentowały informacje na 1-2 stron, podczas gdy część badanych organizacji wykorzystała do prezentacji tego samego typu informacji ponad 20 stron.

Kolejna różnica, którą zauważono w wyniku analizy, dotyczyła sposobu prezentacji danych, dotyczących wskaźników efektywności środowiskowej.

$\mathrm{Z}$ analizy wynika, że polskie organizacje, zarejestrowane $\mathrm{w}$ systemie EMAS wykorzystują różne formy prezentacji informacji, dotyczących wskaźników efektywności środowiskowej. Zdaniem autorki artykułu, najbardziej czytelną i najłatwiejszą do analizy formą prezentacji danych, jest jedna zbiorcza tabela, w której zawarto wartości wszystkich wskaźników, ujętych w sprawozdawczości. Taką formę prezentacji informacji wykorzystało 15,91\% organizacji, objętych badaniem. Część organizacji, oprócz jednej zbiorczej tabeli (dla wszystkich ujętych w sprawozdawczości wskaźników), wykorzystało dodatkowo do prezentacji danych wykresy - stanowiły one 27,27\% wszystkich organizacji. Niektóre organizacje $(9,1 \%)$ wykorzystały także najbardziej rozbudowaną formę prezentacji informacji, (zbiorcza tabela dla wszystkich wskaźników, osobne tabele dla poszczególnych wskaźników oraz wykresy) - zdaniem autorki artykułu, taka forma prezentacji informacji jest najmniej czytelna i najtrudniejsza do analizy. Kolejną formą 
prezentacji danych, stosowaną przez badane organizacje, były wyłącznie osobne tabele dla poszczególnych wskaźników - zastosowało ją 11,36\% wśród wszystkich organizacji. Taka forma prezentacji danych jest zdaniem autorki artykułu także czytelna. Organizacje wykorzystały także do prezentacji danych osobne tabele dla poszczególnych wskaźników oraz wykresy $(27,27 \%)$. Część organizacji, objętych badaniem, wykorzystała do prezentacji informacji wyłącznie wykresy $(6,82 \%)$, a także wykresy wraz z rysunkiem $(2,27 \%)$.

O trudnościach, związanych $\mathrm{z}$ porównywaniem deklaracji środowiskowych, spowodowanych różnym sposobem prezentacji informacji, pisali także Erkko, Melanin oraz Mickwitz. $^{10}$

\section{WNIOSKI}

Sposób, w jaki organizacje zarejestrowane w systemie EMAS podają w sprawozdawczości informacje, dotyczące wskaźników efektywności środowiskowej, różni się w oczywisty sposób, w zależności od rodzaju prowadzonej przez nie działalności. Nie mniej jednak, nawet w przypadku organizacji, prowadzących podobny rodzaj działalności, sposób podawania tych informacji może różnić się m.in. pod względem: ilości stron, przeznaczonych $\mathrm{w}$ deklaracji do prezentowania tych informacji; formy prezentowania informacji (jedna tabela, kilka tabel, wykresy); jednostkami miar, wykorzystywanymi do podawania wartości wskaźników (liczba A i B); przedziałem czasowym, w którym podano wartości wskaźników. Te liczne różnice powodują, że analiza informacji, dotyczących wskaźników efektywności środowiskowej, jest zadaniem bardzo trudnym i czasochłonnym. Rozporządzenie EMAS III precyzuje wprawdzie, jakie wskaźniki efektywności środowiskowej powinny zostać ujęte w sprawozdawczości (poprzednie wersje rozporządzenia nie precyzowały, jakie mają to być wskaźniki), wciąż jednak zdaniem autorki brakuje bardziej dokładnych informacji, w jaki sposób wskaźniki te powinny być podawane. Analiza deklaracji środowiskowych, polskich organizacji zarejestrowanych w systemie EMAS wykazała wiele różnic, dotyczących sposobu prezentowania informacji, dotyczących wskaźników efektywności środowiskowej. Zdaniem autorki należałoby opracować jednolity format, w jakim informacje, dotyczące wskaźników efektywności środowiskowej, powinny być prezentowane (możliwy do zastosowania przez wszystkie organizacje, zarejestrowane w systemie EMAS). Unifikacja mogłaby dotyczyć m.in. formy prezentowania informacji (np. obowiązkowa jedna zbiorcza tabela dla wszystkich wskaźników); jednostek miar dla głównych wskaźników, które nie są uzależnione od rodzaju prowadzonej działalności oraz szeregów czasowych, w jakich podaje się wartości wskaźników. To z całą pewnością ułatwiłoby trudny proces analizy informacji, dotyczących wskaźników efektywności środowiskowej, zawartych w deklaracjach środowiskowych.

${ }^{10}$ Erkko S., Melanen M., Mickwitz P., Eco-efficiency in the Finnish EMAS reports - a buzz world? „Journal of Cleaner Production 13”,2005, pp.802. 


\section{LITERATURA}

[1] Deklaracje środowiskowe organizacji zarejestrowanych $w$ systemie EMAS, dostępne na stronie www.gdos.gov.pl.

[2] Erkko S., Melanen M., Mickwitz P., Eco-efficiency in the Finnish EMAS reports a buzz world? „Journal of Cleaner Production 13”,2005.

[3] EVER: Evaluation of EMAS and Eco-Label for their Revision. Report 2: Research Findings, 26 December 2005.

[4] Rozporzadzenie Parlamentu Europejskiego i Rady (WE) NR 1221/2009 z dnia 25 listopada 2009 r. $w$ sprawie dobrowolnego udziatu organizacji $w$ systemie ekozarządzania i audytu we Wspólnocie (EMAS), uchylajace rozporządzenie (WE) nr 761/2001 oraz decyzje Komisji 2001/681/WE i 2006/193/WE.

\section{DIFFERENCES IN THE WAY OF PRESENTING THE INFORMATION CONCERNING THE ENVIRONMENTAL PERFORMANCE INDICATORS}

One of the requirements of Eco-Management and Audit Scheme (EMAS) is to publish the environmental statement. The environmental statement is a form of environmental reporting, which includes information about for example: environmental management system, environmental aspects, environmental objectives and targets, and environmental performance (including environmental performance indicators). EMAS Regulation specifies what should be the minimum content of the environmental statement, but organization decides what details will be included in the declaration and what will be its structure and layout. EMAS Regulation (Annex IV) lists six key environmental performance indicators that should be included in the environmental statement. They relate to: energy efficiency, efficient use of materials, water, waste, biodiversity and emissions. Organizations can also include in their environmental statement additional indicators if they consider them to be significant for the identified significant environmental aspects.

Environmental statements provide many quantitative and qualitative data concerning the environmental performance of the organization. Their analysis and comparing the data contained in the individual declarations is not an easy task. The reason of this situation are differences in the way of presenting the information by individual organizations.

This article describes differences in the way of presenting the information (concerning the environmental performance indicators) in the environmental statements of organizations registered under EMAS. The article includes an analysis of environmental statements, which were available on the EMAS website. The study concerned all Polish organizations registered under EMAS on 24022014.

Keywords: EMAS, environmental performance indicators, environmental statement.

DOI:10.7862/rz.2014.hss.45

Przesłano do redakcji: luty 2014

Przyjęto do druku: październik 2014 